\title{
From airfield to airport: an institutionalist-historical approach to the early development of Amsterdam Airport Schiphol, 1916-1940
}

Dr. A. (Abdel) El Makhloufi, Faculty of Arts, VU University Amsterdam, The Netherlands, De Boelelaan 1105, NL-1081 HV Amsterdam, a.el.makhloufi@let.vu.nl

Dr H. (Harm) Kaal, Faculty of Arts, Radboud University Nijmegen, The Netherlands, P.O Box 9103, NL-6500 HD Nijmegen, h.kaal@let.ru.nl

Dr. Harm Kaal (1977) is a university lecturer in political history at the Faculty of Arts of Radboud University Nijmegen. His current research deals with the regulation of political manifestations and with 'the livable city' and urban politics in the twentieth century. Recently, he has worked an a comparative research project on the regulation of public politics in the Netherlands and Great Britain at the Faculty of History of the University of Cambridge on a British Council Researcher Exchange Grant. His recent publications include "Running the Big City: the Dutch Pre-War Mayoralty Under Construction, " European Review of History 16, 4 (2009) 437-452, "Immigrants in the polder: rural-rural long distance migration in North-western Europe: the case of Watergraafsmeer," Rural History 20, 1 (2009) 99-117 (with Jelle van Lottum) and "Democratie onder druk: de reglementering van politieke manifestaties in Amsterdam tijdens het interbellum," Low Countries Historical Review / BMGN 124, 2 (2009) 186-208.

Dr. A. (Abdel) El Makhloufi is a post-doc researcher at the Faculty of Arts, department of Economic and Social History (ESG) of the VU University Amsterdam. His main research interests are: Regional and Urban Economics; Economic Geography; Institutional Economics; International Economics and Development Economics. His main recent publications are: "Dynamic Externalities, Local Industrial Structure and Economic Development: Panel Data Evidence for Morocco" (with Maurice Bun), Regional Studies, 2007, 41(6), 1-15; "Exports and Productivity: Moroccan Manufacturing 1985-1995” (with Maurice Bun), Journal of Economic and Social Geography, 2006, 97(2), 157-165. 


\title{
From airfield to airport: an institutionalist-historical approach to the early development of Amsterdam Airport Schiphol, 1916-1940
}

\begin{abstract}
In this paper, the development of Dutch airports during the antebellum period from military airfields to mixed-airfields and finally to a municipal airports is examined from an institutionalist-historical approach. Specific attention is given to the evolution of Amsterdam Airport Schiphol within a regional socio-economic context and within a national context of local competition, particularly between the big cities in Randstad Holland. This paper argues that the rise and development of Schiphol and its impact on the surrounding urban area (city and the region) can be characterized as a co-evolutionary process involving different actors within various domains - economic, political and institutional - and at different spatial levels. Airport development, therefore, has to be conceived as the result of a collective arrangement which has determined the spatial and economic development of the airport itself and the surrounding area.
\end{abstract}

Keywords: collective arrangements, institutions, municipal airports, Schiphol Airport.

\section{Introduction}

Saturday, 2nd July 1938 thousands of people gathered at Amsterdam Airport Schiphol to demonstrate against the national government's plans for the establishment of a new, national airport somewhere near the city of The Hague. The Ministry of Waterworks in cooperation with the National Aviation Board and KLM, the Royal Dutch airline company, was determined to construct a new, modern airport at a central location in Randstad Holland (the metropolitan area formed by the four big cities of Amsterdam, The Hague, Rotterdam and Utrecht), which would replace - or at least marginalize - the existing airports near Amsterdam and Rotterdam: Schiphol and Waalhaven. If this plan was to be carried out, Schiphol would indefinitely lose its status as the Dutch main airport - a status which it had managed to establish over the past two decades of its existence. According to one of the initiators of the protest meeting the citizens of Amsterdam were keen to 
proof that 'they loved Schiphol and considered the airport to be an integral part of their beloved city and could not accept the amputation of such an important part of Amsterdam life'. ${ }^{1}$ Speeches were made by G.H. Crone, the chairman of the chamber of commerce, G.C.J.D. Kropman, the city's Commissioner of Commerce and A.F. Bronsing, the director of an Amsterdam steamboat company, all stressing the importance of Schiphol for Amsterdam to maintain its status as a centre of traffic, commerce and industry. Moreover, the proximity of the airport to the economic capital of the country was explicitly mentioned as a prerequisite for airport development. In turn, the presence of the airport near Amsterdam was considered as crucial for the future economic development of the city: Schiphol needed Amsterdam as much as Amsterdam needed Schiphol. Hence, the construction of a new airport many miles away from the Amsterdam region was an example of a complete lack of understanding regarding airport development - at least according to those gathered at Schiphol. ${ }^{2}$ Finally, members of the Amsterdam city council were embittered by the fact that the national government only started to show interest in airport development at a time when Schiphol finally had developed into one of the best equipped European airports after many years of financial investments by the municipal government. Eventually, as will be explained later on, Amsterdam managed to turn the tide in its favour: instead of constructing a new airport, after the Second World War national government would decide to officially reestablish Schiphol as the 'Dutch National Airport' ${ }^{3}$

The nature and background of the demonstration at Schiphol airport raises a couple of intriguing and relevant questions with regard to the early history of Dutch airport development. In the Netherlands airport development apparently involved actors at different spatial levels, for instance representatives of both the national and the local government, and within different domains: government, business and civil society. This article aims to explain this notable political and social involvement in Dutch airport development throughout the first decades of its existence through a focus on the interaction between the main actors and the key political, social and 
economic factors which have determined the early history of Schiphol and other Dutch airports. We will particularly explore the institutional and economic relations between the airport and the city of Amsterdam, the (economic) capital of the Netherlands, as well as the relations between Schiphol and rival Dutch airports near The Hague, the center of Dutch national government, and Rotterdam, the nation's largest port city, which competed with Schiphol in the early stages of Dutch airport development for the status of 'national airport'.

Despite the wave of studies on airport development in Europe and the USA which have been published over the past two decades, research focusing on the wider implications and interdependency of airport and urban development has been scarce. Most studies deal with specific topics such as airport design, architecture and engineering, infrastructure, the early history of single airports, or the remarkable feats of aviation pioneers, like Brodherson's research on the construction and design of airport facilities and installations in the early days of the development of airports, Douglas' study on the evolution of technology and the increased complexity of airports, Myerscough's excellent survey of the provision of British aerodromes and airports during the interwar years and Dierikx and Bouwens' extensive monograph on the history of the Airport Schiphol in the European context which also primarily focuses on airport architecture and design. ${ }^{4}$ Moreover, the 1990s witnessed a plethora of case studies of individual airports in the USA. ${ }^{5}$

These studies, nonetheless, have touched upon very relevant issues with regard to airport history. Bednarek for instance has posed one of the key questions which also applies to our investigation: how and why were airports at first run by municipal authorities? In both the USA and the Netherlands, as opposed to many other European countries, airport development at first was a local issue. The construction of airports was the result of collective efforts of local politicians and businessmen who believed in the impact aviation could have on their cities and businesses. According to Bednarek financial considerations were key in the involvement of local actors; federal institutions which were to benefit from airport development, but lacked the money to actively 
support it, like the US Post Office, looked to municipal governments or other local (business) interest groups for support. Fueled by local boosterism - aimed at improving the local economy civic pride or a strong belief in the future of aviation, many cities took up the challenge. ${ }^{6}$ Although Bednarek's analysis cannot simply be applied to our case - for instance because of huge differences in the financial relations between cities and the national government in the Netherlands and the US - her study has signaled the need to approach the early history of airport development from various perspectives. After all, apart from important economic and infrastructural functions, airports also possess important cultural and institutional aspects such as image, perception and collective governance, which involves various actors at different spatial levels - local, regional, national and international - and in different institutional settings in state and society like public authorities, businessmen, city planners, architects, technicians and engineers. ${ }^{7}$

For our analysis of the interplay between the various actors involved in airport development the concept of collective arrangements will be used. Collective arrangement is a key concept in institutional economics, an economic discipline which comprises a wide range of approaches highlighting the important role of institutions and institutional structure in the economy and society. ${ }^{8}$ We define a collective arrangement as a set of processes, ideas, visions, actors and factors which produce rules, norms, values, conventions, and policies within a certain institutional setting. As such, a collective arrangement constrains and structures the behavior of and interaction between the different actors within the institutional setting. Collective arrangements may be formal or informal, they may involve two or more individuals or organizations, and they may be temporary or long lived. In any case, collective arrangements are bound in time and space in the sense that they are created in a specific historical context and in specific places. Applied to our investigation of the early history of Schiphol a 'collective arrangement' is seen as the result of a combination of policy, agreements, governance structure, and economic support (for instance investments) aimed at the creation, improvement and transformation of the airport's economic and spatial structure in relation 
to its wider urban or regional environment. In turn, the interactions between different actors and factors either directly or indirectly influence the long term development trajectory of the airports and their spatial and economic configuration. In this sense, the structure of collective arrangements is shaped through the interplay of people, goods, money, knowledge and information and the accompanying social-economic and spatial interventions, agreements and regulations.

The rise and development of Schiphol airport during the 1920s and 1930s may be viewed as the result of successive collective arrangements which have structured and determined the development and growth of the airport on the long run. The demonstration at Schiphol airport for instance was part of the emergence of a new collective arrangement, which eventually led to the establishment of Schiphol as a national airport after the Second World War, which would replace the existing collective arrangement regarding Schiphol as a municipal airport. Different actors at the local, regional, and national level were involved in determining the contours of this new collective arrangement which could only be formally established after long negotiations, discussions and research. We distinguish between three principal actors which were involved in the development of Schiphol airport: individuals (key persons from civil aviation or aviation enthusiasts, members of local business communities and users of airport services), local government or representative entities such as municipalities, city councils and chambers of commerce and the state which includes supralocal (regional) and national bodies like ministries and national (semi)public institutions like the National Aviation Board.

In the next section we will identify these actors, elaborate on their specific role, motivations, objectives as well as their formal and informal position vis-à-vis other actors, and explore how they contributed to the emergence and transformation of the collective arrangements which have directed the development of Schiphol and its wider region from 1916 onwards. Apart from their formal nature, collective arrangements, however, also exude certain collective representations and perceptions with regard to airport and urban development, like visions of the future of airports and 
aviation, as manifested in spatial planning concepts and designs. ${ }^{9}$ Those issues will be discussed in the second section when we elaborate on the Dutch 'airport-battle': the competition between the municipal airports in Amsterdam and Rotterdam and the debate about the establishment of a new national airport as mentioned in the start of our introduction.

\section{Collective arrangements and the early history of Schiphol}

The collective arrangement which has formed the basis for the creation of Schiphol in 1916 was the Dutch Ministry of War's decision to construct a military airfield in the Haarlemmermeer polder, an agrarian municipality to the southwest of Amsterdam (see map 1 bellow showing the location of Schiphol and Amsterdam). Schiphol was one of several small military airfields across the country, but the only military airfield within the Fortress Holland (in Dutch: Vesting Holland) which formed the key element of the Dutch defensive strategy. The Schiphol military airfield was located in the northeastern part of the Haarlemmermeer. The choice for this location was not an arbitrary decision but the result of an extensive search for a suitable location for a new military airfield by the Commandant of the department of aviation, captain H. Wallard Sacré. After two unsuccessful attempts to build a military airfield in two different locations in the vicinity of artillery sites near Amsterdam, the military decided to construct the new military airfield at Schiphol. ${ }^{10}$ As soon as Schiphol airfield became operational, it, however, turned out to be too small for landing military aircraft; especially in crosswind. The landing and starting of airplanes needed a minimum surface of approximately 80 by 80 meter. Between May and November 1917, the military therefore decided to expropriate seventeen parcels of land from different private owners. As result, the size of Schiphol grew to 60 ha at the end of 1917 and 76 ha by the end of 1920. The airfield's physical conditions were, however, deplorable because of lack of good drainage facilities and the absence of electricity and water supply. During the rainfall season, the airfield turned into a muddy terrain; Schiphol was known among the pilots as 'Schiphol Les Bains'. 


\section{Map 1. The location of Schiphol airport within the Amsterdam-Haarlemmermeer region (c.}

\section{7) $\rightarrow$ Insert about here}

Throughout the 1920s the development of Schiphol was guided by a relatively clear and simple collective arrangement. By this we mean that the number of actors and persons involved was limited and most of them knew each other. Apart from the Ministries of War and Public Works a few other actors were involved in the development of Schiphol, particularly the city of Amsterdam, Dutch airline company KLM, the Dutch Air Traffic council (hereafter RLD), and to a lesser extent Fokker, the leading Dutch aircraft manufacturer. Amsterdam had started to show increasing interest in the airbase after a successful aviation exhibition which was organized in 1919: the First International Air traffic Exhibition Amsterdam (hereafter: ELTA). Many aviation enthusiasts were involved in the organization of this event ranging from people belonging to the Amsterdam financial sector such as Eddy Fuld, a prominent Amsterdam banker and a future member of the supervisory board of KLM, representatives of the Dutch military - General C.J. Snijders, Captain Wallard Sacré and Lieutenant pilot M.L.J. Hofstee - and members of the city council of Amsterdam, particularly liberal councilor D. Manassen. During six weeks more than 500.000 people visited the ELTA exhibition and admired the impressive Handley Page Bomber, the Vickers Vimy Bomber and Dutch airplanes manufactured by Fokker, Trompenburg and Van Berkel. After the exhibition the ELTA buildings were put into use by Anthony Fokker's aircraft manufacturing company. Building on the successful organization of the ELTA, a group of prominent persons from the business world (financiers, bankers and businessmen) decided to join force to create a Dutch airline company: KLM, headed by Albert Plesman. ${ }^{11}$ The stakeholders of the KLM were several Dutch banks and major trade and shipping companies. ${ }^{12}$ KLM immediately asked permission to use Schiphol for commercial activities after signing an agreement with the post office in March 1920 for transporting airmail between the cities of Amsterdam and London. In May 1920, the first 
commercial aircraft landed at Schiphol military airfield and in in June 1920, the military airfield Schiphol was officially declared open to commercial traffic, albeit partly and with a maximum of 30 flights per month. Schiphol nonetheless quickly developed into an important airport in the emerging European network of air services as KLM increased its operations and opened new line services such as those to Hamburg and Copenhagen which started in September $1920 .^{13}$

\section{Map 2. Military airfield Schiphol (1919-1926) $\rightarrow$ [insert about here]}

With opening access to civil aviation the initial collective arrangement regarding Schiphol as a military airfield was replaced by a new, more complex arrangement which transformed Schiphol into a mixed airfield. The establishment of this new collective arrangement opened new opportunities for further development of Schiphol from a military to a civil airport and sets Schiphol apart from other Dutch airports who maintained their military status. In fact Schiphol was now governed by two State Ministries - the ministry of War and the ministry of Public Works which was responsible for civil aviation operations - but was primarily operated by personnel of the Ministry of War. ${ }^{14}$ Other key actors within this collective arrangement were KLM-director Albert Plesman and Dutch airplane constructor and aviator Antony Fokker. Both, as we will see, more or less had their own vision on the development of Schiphol, but each of them played an essential role in the early development of the airport. The relationship between Plesman and Fokker was as much characterized by cooperation as conflicts. Both were visionary and pragmatic persons with great passion for the civil aviation in general and fervent proponents of the development of Dutch civil aviation in particular. A large part of the KLM fleet consisted of Fokker aircraft; in fact the early development of the Dutch civil aviation, KLM and Fokker were closely intertwined. ${ }^{15}$ The relationship between these two companies and their relationship with Schiphol was of great importance for the development of commercial aviation in the Netherlands: Fokker furnished new airplanes to KLM and the performances of KLM helped to promote the Fokker airplanes. Plesman, 
however, was first and foremost a businessman with a commercial mentality which surpassed nationalistic feelings. When Douglas started to produce its famous DC series in the 1930s Plesman did not hesitate to purchase these aircrafts and set up Fokker airplanes aside. ${ }^{16}$ In the eyes of Plesman, KLM was more important than friendship. This also applied, as will be discussed below, to the relationship between Plesman and Schiphol-representatives, particularly the managing director of the airport Jan Dellaert.

In the early 1920s, with the increase of the scope and size of services provided by the military for an ever growing number of civil aircraft and the rising costs of airfield services - like the lighting of the landing ground, fire control, medical services and passport checks - the coexistence of two different air activities at the same airfield was questioned by the military authorities. Moreover, the military lacked the financial means to make necessary improvements to airport infrastructure. Schiphol lacked, among other things, terminal buildings, hangars and passengers check-in desks. Moreover, Schiphol was not properly connected with Amsterdam by road or train; the only transport system connecting Schiphol and Amsterdam was a KLM bus service. People travelling by car were forced to pass through two toll bridges and cross a narrow bridge over the Rijnvaart canal encircling the Haarlemmermeerpolder before reaching the airport. The 11,5 kilometers from Amsterdam to Schiphol took over thirty minutes or more. ${ }^{17}$

Both the Ministry of War and KLM pinned their hopes on the Amsterdam government to improve the conditions at Schiphol. They were supported by the Amsterdam Chamber of Commerce which considered the development of Schiphol to be one of the main contributors to the future economic development of the city. The airport was expected to act as a magnet for attracting firms and activities to Amsterdam. Moreover, the Amsterdam business elite, people like Eddy Fuld who had been involved in ELTA and others who were financially involved in KLM and Fokker, wanted to secure their investments. The municipality, however, appeared to lack the expertise, political power and financial means to effectively operate and manage an airport. Despite the fact 
that almost none of the European and American airports and airlines at the time were able to gain profit, Amsterdam municipal government was, nonetheless, keen to take over Schiphol and invest in its future development. In 1926 the Amsterdam city council almost unanimously decided to take over Schiphol. ${ }^{18}$ Amsterdam got the right to manage and exploit the municipal airport for a period of 10 years with an option for another thirty years. Following this agreement between the municipality of Amsterdam and the ministries of War and of Public Works, the airport was managed and operated by Amsterdam and only a small part of the airport was preserved as a military terrain. In 1935 Amsterdam agreed to take over the military part as well. ${ }^{19}$

The emergence of a network of local lobbyists and national businessmen was key in turning airport development from an issue of military strategy or mere aviation enthusiasm into an economic issue using a rhetoric of progress and modernity which fed into the self-perceived need of Amstedam governors to improve their city's economic potential and competitiveness and therefore managed to persuade the Amsterdam city council to take over Schiphol airport. ${ }^{20}$ Key figures and institutions within the new collective arrangement were Schiphol-director Jan Dellaert, members of the Amsterdam Chamber of Commerce, Amsterdam mayor Willem de Vlugt and various municipal departments. Like Plesman, Dellaert had started his career as a pilot; both had attended the military school at Soesterberg airfield near Utrecht. When KLM settled at Schiphol in the early 1920s Plesman asked Dellaert to act as chief of the station building. He was a man with great knowledge of aviation and a very competent manager. When the municipality of Amsterdam took over the airport from the military in 1926, Dellaert would be appointed as the first managing director of the municipal airport. Thanks to his personal relationship with Plesman, he was able to defend the interests of the municipal airport as well as the interest of the main user of airport facilities: KLM. Moreover Dellaert was aware of the fact that the futures of KLM and Schiphol were closely intertwined. Dellaert made sure Amsterdam kept investing in airport facilities in order to commit KLM to Schiphol and improve the competitive position of Schiphol in Europe. ${ }^{21}$ 
The chamber of commerce consisted of local representatives of trade and business who were dedicated to the protection and promotion of business interests and who often also belonged to the city's social elite and were therefore ensured of access to the worlds of government and finance. Ernst Heldring, chairman of the Amsterdam chamber of commerce in the 1920s was a prominent member of the liberal party, born into a wealthy, upper class family and famous for his numerous additional activities in social and cultural life. ${ }^{22}$ Like their colleagues in The Hague and Rotterdam, the Amsterdam chamber showed great interest in the development of aviation and pressed for local governmental intervention in municipal airport development. ${ }^{23}$

Within Amsterdam local government mayor De Vlugt in particular was occupied with connecting the world of politics and business in order to boost the city's economy, using his contacts at different levels of government and his ties with Dutch businessmen. De Vlugt for instance exerted himself to reach an agreement with the national government on the construction of a new connection of the Amsterdam harbour with the Rhine and was involved in bringing the 1928 Olympic Games to the city of Amsterdam. ${ }^{24}$ The fact that he was able to do so had everything to do with the political willingness of Amsterdam councillors and aldermen to invest in their city's (economic) future. ${ }^{25}$ The enthusiasm of De Vlugt, Dellaert and the chamber of commerce for airport development was not based on clear-cut economic calculations, but was merely fed by their belief in the winged gospel, a shared belief in the benefits airport development would bring to the city in the future. Outside government the winged gospel was also preached by a group of active individuals in the aeronautical circle such as the Royal Dutch Association of Aviation (De Koninklijke Nederlandse Vereniging voor Luchtvaart (KNVvL). Members of the KNVvL were actively involved in attracting support from national and local authorities and the public for the development of a national civil aviation trough the organization of promotion campaigns, flight shows and the publication of articles, studies and report concerning the future development of aircraft technology and airports for civil aviation, Schiphol in particular ${ }^{26}$. 
From 1926 onwards the development of Schiphol airport would be coordinated by the municipal Department of Commerce, which was responsible for the management of the airport carried out by Dellaert - and the Department of Public Works, which drafted plans for the future expansion and improvement of the airport. Within the Amsterdam municipal planning department, the development of Schiphol airport was treated as a key issue with regard to the overall economic development of Amsterdam and its region. The spatial sprawl of the Amsterdam Region increased rapidly during the 1920s and 1930s with the annexation of a number of surrounding municipalities. The ongoing development of airplane technologies and the corresponding increase of commercial aviation also resulted in the gradual spatial expansion of airport facilities and equipments, which in turn called for a more systematic approach to the development of the airport in the future and its relation to the nearby Amsterdam urban area.

The airport expansion plan for Schiphol was developed in 1935 by the urban planners and urban designers of the city of Amsterdam in cooperation with the airport authorities - particularly the director of trade L. Boogert and the managing director of Schiphol Jan Dellaert - the municipality of Haarlemmermeer, the province of North-Holland and other external experts like engineer professor Zweers from the Delft Polytechnic Academy. ${ }^{27}$ The planners responsible for the development of the expansion plan of Schiphol were the same planners and designers who developed the internationally reknown General Expansion Plan of Amsterdam (AUP) of 1934: Th.K. van Lohuizen, L.S.P. Scheffer and C. van Eesteren. The AUP gained international fame for its innovative urban planning which was based on the combined use of statistical analysis - for instance with regard to transportation infrastructure - and forecasts of population growth. The Schiphol expansion plan not only consisted of the development of the airport itself, but also dealt with issues like housing construction for the employees of Schiphol and the KLM in the surrounding municipalities, the total surface of land to be expropriated from private owners, and the spatial organization of airport facilities. ${ }^{28}$ Moreover, the Schiphol Expansion Plan was integrated 
into the urban expansion plan of the municipality of Haarlemmermeer as a first step to coordinate the expansion of the airport and the surrounding area. In this sense, the future expansion plans for Schiphol constituted an integral part of the overall urban expansion plans of the city of Amsterdam and the municipality of Haarlemmermeer, which clearly indicates the importance of Schiphol as one of the main economic engines, in terms of employment and (freight) transport, for Amsterdam and the region. Barrett's analysis of airport development in the United States which was not conceived at the drawing board, but resulted from the interaction between 'the leaders of corporations and chambers of commerce along with politicians, city engineers, and federal bureaucrats whose decisions determined the relationship between the airport and the city', therefore does not entirely hold true for Schiphol: plans were made at the drawing board and played a part in the discussions about airport and urban development. ${ }^{29}$ Improvements of the airfield and facilities at Schiphol were carried out shortly after Amsterdam had taken over responsibility over the airport. The terrain was renewed and leveled, an underground drainage system was constructed and a big white circle was put at the middle of the landing terrain in order to serve as a clearly visible landmark for landing aircraft. In addition, a large concrete apron was constructed at the front of the KLM hangar, office space was extended and the airport was equipped with a terminal building, paved runways, hangars, radio-installation, lighted beacons and a control tower. Road access to the airport was also improved. Municipal authorities managed to convince the national and provincial government of the need to integrate Schiphol in the national and provincial road network. ${ }^{30}$ Within the course of two decades the rather primitive Schiphol airfield developed into a modern European airport (see Map 3 bellow which shows the situation in 1939 after the expansions of Schiphol).

Map 3. The Spatial Expansion of Schiphol from 1926-1939 $\rightarrow$ [insert about here] 
The improvements at Schiphol were inspired by foreign ideas and experiences. From the second half of the 1920s an international network emerged which generated cooperation among airport operators and facilitated the exchange of experiences, ideas and (technical) information. This usually happened through regular meetings of European airport operators, but also through correspondence, conferences, and publications in professional magazines. Two main technical issues at Schiphol for instance were solved partly by copying practices from other airports, especially in the US: the drainage system and the construction of paved runways. ${ }^{31}$ Compared to foreign airfields like Le Bourget near Paris, Croydon in London or Tempelhof in Berlin, these improvements were, however, much less impressive and very modest in size, design and scope, due to the lack of municipal financial means. It is, however, difficult to compare different airfields across Europe, because of great differentiation between airports in terms of their construction, design, management and exploitation. ${ }^{32}$ While Tempelhof airport and, to a leser extent, Le Bourget benefited from state financial support, Croydon and many other local airports in the UK - like Schiphol - were financially supported by less affluent local governments.

At first, Croydon, like Schiphol, was owned by the military, the Air Ministry, and did not enjoy any attention or support from the national authorities. The equipment of the airport was very modest and its configuration was very simple: a landing terrain with a terminal, a freight building and airline offices and technical departments scattered over the site. In 1926, Croydon was expanded with a new spacious terminal, a control tower, four large hangars, a repair shop and a hotel. In time, however, Croydon lacked space for further expansion of airport facilities and by the mid 1930s, the air ministry decided to build a new airport at Heston which would become the home airport of British Airways. As opposed to Croydon, the French airport Le Bourget managed to rise to dominance in the 1920s. In fact, Le Bourget was the most important airport of Europe until 1934 when Berlin-Tempelhof took over the leading position. Like Schiphol and Croydon, Le Bourget also had its origin in the military. In 1919 the airport was divided into a military section and a civil 
aviation section. The Air Ministry was still responsible for the development of the airport which was reconstructed in the mid 1930s with the erection of, among others, a new terminal building and a motorway connecting the city centre of Paris and Le Bourget.

Tempelhof, the airport of Berlin, was the most modern European airport of the interwar years. The airport was commercially run by the Berlin Airport Company, established in 1924 with the city of Berlin (52 percent), the central government (24 percent) and the state of Prussia (24 percent) as shareholders. ${ }^{33}$ The airport was equipped with an oval shaped landing field, a hard surface apron, and a passenger terminal. The configuration plan of Tempelhof was based on a new approach of passengers handling; air travellers, luggage and freight were separated and handled at different levels of the terminal building. Tempelhof developed into the main hub of an airline network that stretched out to Amsterdam, London, Paris, Vienna, Warsaw, Moscow and Copenhagen. As was the case for many European airports, the terminal facilities soon became too small with the rapid increase in air traffic. It was after Hitler's rise to power in 1933 that expansion of the airport would take shape at a larger scale. The landing terrain was expanded to 1800 by 2300 meters and a colossal terminal complex with a huge departure hall was built in addition to the extensions of aircraft hangars and repair shops and the construction of sheltered parking space for the loading and unloading of passengers and goods which turned Tempelhof in the largest airport in the world at that time. ${ }^{34}$

The faith of these European airports illustrates the fact that airport development depended on the prevailing collective arrangement. In the case of Schiphol, run by the local government, funds were lacking for massive redevelopment. Schiphol registered a continuous financial deficit and the total costs of operating and expanding the airport facilities pushed Amsterdam to seek funds in the financial market, which in turn resulted in high interest payments. This explains why Schiphol was much less impressive in terms of design, size and equipment than, for instance, Tempelhof. 
[Figure 1. Annual Costs, Net Result \& Municipal Subsidies. Source, Annual Reports Municipal Airport Schiphol (1928-1940)]

Eventually, towards the end of the 1930s airport authorities, in this case municipal authorities, turned to the national government for financial support. Due to the economic crisis of the 1930s, the increasing costs and complexity of airport expansion and construction, and the Amsterdam municipal government's chronic lack of funds, public intervention became urgent and financial support from the state was seen as prerequisite to insure the survival of the airport in general and national civil aviation in particular. This did not only apply to Schiphol but also to the majority of other European airports which were operated by local authorities or private airport operators. ${ }^{35}$ The Dutch national government in turn aimed to strategically invest their money in an airport which appeared fit to face the challenges of the future, rapid development of aviation. This meant that a choice had to be made between Schiphol and its main competitor Waalhaven, but the national government also studied the possibility of constructing a new national, 'central' airport in Randstad Holland. In Amsterdam those plans, as mentioned in the introduction, were met with fierce prostests. This debate about the future of Dutch aviation, and the local boosterism and competition which accompanied it, will be discussed in the next section in order to explore the growing complexity of the different collective arrangements which have characterized the early history of Dutch aviation.

\section{The Dutch airport battle}

In the 1920s and 30s several plans were presented for either the expansion of existing airports or the construction of new ones near Rotterdam, the Hague and Amsterdam or in between these cities, in an area better known as Randstad Holland. The Dutch 'airport battle' was driven to a great extent 
by the involvement of the chambers of commerce and the municipal government of Amsterdam, Rotterdam and The Hague. Local boosterism, efforts to diversify the city's economic structure and the urge to 'think modern' turned airport development into an important element of metropolitan politics. In Amsterdam local boosterism was particularly produced by mayor De Vlugt and the city's Chamber of Commerce which can be best understood against the background of Amsterdam's recent economic history.

In the nineteenth century Amsterdam had forever - or so it seemed - lost its status as one of Europe's major economic centers. Already in the eighteenth century the city had lost much of its economic vitality. While England had built up an entirely new type of industrial production based on steam and coal, the industries of the Amsterdam-Zaan region still mostly relied on wind and water power. It took until the last quarter of the nineteenth century for this to change. A new, progressive political culture ended the erstwhile dominant laissez-faire policy of the local governors. Moreover, a new commercial and industrial elite, profiting from extensive exploitation of the Dutch East Indies, was willing to invest in their city's future. The local government together with the national government started to invest in the city's infrastructure: 1876 marked the opening of the North Sea Channel, which connected the Amsterdam harbour to the North Sea near the city of IJmuiden. The following decades Amsterdam invested in the construction of a new waterway connecting the harbour with the Rhine, thus ensuring a connection with the economically very important German hinterland. ${ }^{36}$ Despite these investments, Amsterdam entered the twentieth century predominantly as a cultural and financial center. Thanks to its better connections with the sea and Germany, Rotterdam emerged as the Dutch main port and the industrial capital of the Netherlands. The Amsterdam economy, on the other hand, was dominated by the transportation, commercial and financial sectors. ${ }^{37}$ Urban government, nonetheless, was still ambitious enough to try and compete with Rotterdam. 
Since airports were seen as complementary to the harbor activities, both cities were willing to invest in the development of an airfield. When Rotterdam established a municipal airport in 1921, airport Waalhaven, Amsterdam was determined to follow suit. In fact airport development in both cities was closely associated with the urban governments' efforts to maintain their city's economic position vis-à-vis each other. ${ }^{38}$ Rotterdam airport Waalhaven boasted a modern infrastructure, whereas the more primitive Schiphol airport offered better possibilities for future expansion. In Rotterdam the city council decided to offer interesting cost advantages - for instance reduced landing fees - and subsidies to airline companies which used the facilities of the airport. The Amsterdam city council in turn urged for the expansion of the existing airport.

In this sense the urban governors' response to the development of civil aviation in general and Schiphol and Waalhaven airport in particular reflected a mix of 'traditional local boosterism' and a belief in 'the winged gospel'. Urban government was keen stimulate growth and development, which often resulted in competition with rival cities. Airports and aviation in general played a significant role in these efforts to boost the image of 'modernity'. The Dutch took pride in the achievements of KLM and Fokker as is illustrated by the celebrations surrounding air races and the media coverage of pioneering flights. ${ }^{39}$ As illustrated by Bednarek, some aviation enthusiasts were merely in the ban of the 'winged gospel', unconstrained by economic or political considerations. KLM-director Plesman, for instance, was not concerned with the boost aviation could give to the urban development of Rotterdam and Amsterdam, and instead was motivated by a true belief in the unlimited opportunities of aviation and the pivotal role of the KLM. ${ }^{40}$ Furthermore, there was a widely shared believe in the future opportunities of air transportation in linking countries and continents, which was marked by Charles Lindbergh's pioneering transatlantic flight in 1927. The same year KLM carried out two successful return flights to Batavia, the capital city of the Dutch East Indies, which aroused considerable public enthusiasm. ${ }^{41}$ Moreover, the 
annual reports of Schiphol and KLM during the inter-war years show a continuous increase in the number of passengers, freight and post transport (see figure. 2 bellow).

\section{Figure 2. Development of passengers, freight and post transport by KLM or through}

\section{Schiphol. $\rightarrow$ [Insert about here]}

In Rotterdam airport development had been initiated by the municipal authorities. In 1919 mayor Zimmerman urged his commissioners to actively promote aviation in their city. A year later Zimmerman paid a visit to Schiphol in preparation for the construction of an airport near the city of Rotterdam. As opposed to Amsterdam, Rotterdam opted for a location in the dock area, based on the belief in the importance of seaplanes. ${ }^{42}$ This would soon turn out to be an unlucky decision. The Waalhaven location did not offer any possibilities for further expansion. Moreover, the airport was located on the south bank of the river Maas and therefore was not easy to reach from Rotterdam city center nor from the city of The Hague. ${ }^{43}$ Instead of investing in the construction of a new airport, municipal authorities in Rotterdam, nonetheless, kept investing in the modernization of Waalhaven, even when negotiations with The Hague about the establishment of a new airport were well under way. ${ }^{44}$

The Hague, the political and administrative center of the Netherlands, lacked a civilian airport. In 1924 the city's chamber of commerce presented a report to the city council, arguing for the construction of a new airport near the city. The mayor of The Hague, however, was rather pessimistic. According to mayor Patijn it would at least take twenty years before The Hague could be equipped with its own airport; it was not the dynamic urban policy making the Chamber of Commerce was hoping for. ${ }^{45}$ Eventually, after continuing pressure from local businessmen, the municipal government did decide to explore the opportunities for a municipal airport adopting several strategies. First of all, The Hague explored possibilities to establish a municipal airport in or 
near the city. Second, municipal authorities tried to convince their Rotterdam colleagues to cooperate and develop a joint airport in between both cities. Third, urban government supported plans for the construction of a new national airport in Randstad Holland which should replace the existing airports near Rotterdam and Amsterdam. For financial reasons, The Hague urban governors initially opted for cooperation with nearby Rotterdam. When they approached their Rotterdam colleagues to discuss the establishment of a joint airport in between both cities, Rotterdam wanted to be financially compensated for their investments in Waalhaven. At first the urban government of The Hague agreed and plans were made for a new airport in a polder to the Northwest of Rotterdam, near the highway which connected the city to Delft and The Hague: plan-airport Delft. Waalhaven was to be sold to the Ministry of War. ${ }^{46}$ Eventually, however, The Hague again backed out. Mayor Bosch van Rosenthal, who succeeded Patijn in 1930, when the world economic crisis first emerged in the Netherlands, was not prepared to invest in airport development.

Meanwhile, Rotterdam kept investing in its Waalhaven airport in order to keep up with Schiphol, which further jeopardized the plans for the construction of a new airport near Delft. Waalhaven, however, was soon stretched to its limits; eventually local government acknowledged that in order to keep up with Schiphol a new airport had to be established. The Ministry of War was prepared to buy Waalhaven to acquire a military airfield at a strategic position in the Dutch defense system. Rotterdam wanted to use the money to construct of a new municipal airport to the northwest of the city near the motorway to Delft and The Hague: plan-airport Zestienhoven. ${ }^{47}$

Amsterdam looked at the Rotterdam plans with Argus' eyes and was determined to meet the challenge. Several plans were made in order to upgrade and modernize Schiphol airport. In 1934 Plesman launched his plan for the construction of a new airport in the Haarlemmermeer just north of the existing Schiphol airport. In order to improve the access to Schiphol, Plesman urged for the construction of a new terminal building near the new motorway between Amsterdam and The Hague. In reaction to Plesman's plan, which appeared to be too expensive for the city's tight 
financial budget, Amsterdam authorities presented an alternative which amounted to the construction of a second terminal 200 meter west of the existing one, with concrete taxiways around the turf of the landing ground in order to improve take-off and landing. This plan was much cheaper than the Plesman plan. In the mean time, also Anthony Fokker was working on a plan for the future development of Schiphol airport. In his concept, the layout of the airport was based on a large circular landing with a central 'traffic island' in the middle where all passengers and cargo handling could take place. The central traffic island could be accessed through a tunnel to avoid any obstacles on the landing terrain. In this way an optimum operational use of the airport could be reached. The layout of the terminal could be circular or 'horse-shoe' shaped, depending on the airport's general layout. ${ }^{48}$ Also Fokker's plan turned out to be too expensive and the city council instead opted for the expansion of existing facilities at Schiphol airport. At the height of the economic crisis, Schiphol was equipped with a new runway system, consisting of four runways, one in concrete - and an enlarged terminal building and control tower. Schiphol had become one of Europe's largest airports in terms of its surface. ${ }^{49}$

Simultaneously, however, the national government, instigated by Plesman was working on a plan to build a new airport near Leiderdorp, a village to the northeast of The Hague, near the city of Leiden. This location was chosen for its central location in between The Hague, Rotterdam and Amsterdam, and its accessibility by road. Strikingly, the city which had been least inclined to invest in airport development was to be equipped with a modern airport in its immediate surroundings. According to Plesman and J.A.M. van Buuren, minister of Public Works (1937-1939), the rapid development of aviation called for a national approach to the airport-question. Since a small country like the Netherlands could only afford one, modern-equipped national airport, investments in aviation had to be controlled by the national government. From a planning perspective, Dutch airport development therefore required national coordination. Existing airports near Rotterdam and Amsterdam appeared to be improperly located: unfit to meet the rapid developments of aviation 
because of the composition of the soil or the lack of extension possibilities. The proponents of a systematic planning approach to airport development, arguing for a central location in Randstad Holland, however, ignored the interrelationship between airports and their urban surroudings; an interrelationship which had enabled the rapid development of Schiphol and Waalhaven, but which was entirely absent from most airport and urban planning schemes. This only adds to the uniqueness of the Amsterdam municipal planning department's plans for the future development of the Amsterdam region, which showed the department's awareness of the need to integrate the future development of both airport and city. Most urban planning elsewhere, however, was merely aimed at resolving local problems such as housing shortage, transport congestion, employment and the attraction of economic activities. The systematic integration of infrastructure planning in urban expansion plans was limited or totally absent. ${ }^{50}$ Like the national government also Plesman was not occupied with the regional impact of airport development. His views in this respect were driven by financial concerns and his dissatisfaction with developments at Schiphol, where spending cuts had hampered a complete reconstruction as envisaged by the KLM-director.

Amsterdam and Rotterdam reacted furiously to plan-airport Leiderdorp, but Amsterdam appeared to be most successful in generating public protest. A civilian committee by the name of 'S.O.S. Schiphol' was established by the chamber of commerce of Amsterdam, consisting of representatives of the Amsterdam business elite, political and social local movements, and started to mobilise press support for the Schiphol-cause. As mentioned in the introduction, 15.000 people gathered at Schiphol airport in July 1938 to demonstrate against plan-airport Leiderdorp. In this case planning discourse of course was unfit to press the cause of Schiphol: demonstrators referred to historical developments which had brought about the emergence of a modern airport near Amsterdam and the economic necessity of the airport for the urban economy to support their cause. The Amsterdam municipal government pressed the national government to designate Schiphol as the Dutch national airport. ${ }^{51}$ Rotterdam now feared it would loose out to Amsterdam, despite the - 
rather tame - efforts of its chamber of commerce to press the case for airport development in or near Rotterdam. In fact, when the national government, confronted with fierce opposition, decided to abort plan-airport Leiderdorp in September 1938 and assign Schiphol the status of national airport, Rotterdam faced a new battle. ${ }^{52}$

The national government's rather inconsistent policy was met with fierce criticism and amounted to the establishment of the National Commission for the Settlement of the Airport Question. ${ }^{53}$ Meanwhile, the national government started negotiations with Amsterdam about the administrative reorganization of Schiphol airport which was to be turned into a public corporation in which both the national government and the municipality of Amsterdam would participate with the national government holding a majority interest of 60 percent. The establishment of a public corporation would enhance the possibility to finance the future development of the airport, since the municipal budget of Amsterdam was already stretched to - or even beyond - its limits. Discussions about the future of Schiphol continued well into the Second World War, despite the demolition of parts of the airport in May 1940 and the reestablishment of Schiphol as an operational base of the German Luftwaffe in July 1940. Dellaert, Plesman and representatives of the national government went underground to discuss rather technical and theoretical issues with regard to the airport layout - tangential or parallel - lighting, radio installations, safety regulations and infrastructure. ${ }^{54}$ The actual circumstances may have contributed to the development of future plans for Schiphol unhampered by the pre-war conditions: in 1943 and 1944 Schiphol was gradually destructed by allied bombings and German efforts to dismantle the airport on retreat.

\section{Conclusion}

Collective arrangements are dynamic: they are subject to transformation and change as is illustrated by the early history of Schiphol aiport. The basic collective arrangement which lay at the basis of Schiphol as a military airfield transformed into a mixed airport between 1919-1926 before 
becoming a municipal airport in 1926. In fact, the key factor for the rapid development of Schiphol airport was the shift from a mixed airfield to a municipal airport. Schiphol had now turned into a predominantly local, municipal project, albeit of national significance. Where the previous collective arrangement had lacked a catalyst actor, the municipal government now took the initiative. Non-local actors were forced to renegotiate their position vis-à-vis Schiphol whose development was now primarily directed by the interests of the city of Amsterdam. The success of the municipal approach to the development of Schiphol in turn eventually necessitated the involvement of national state actors: in the 1930s municipally-owned Schiphol turned into an airport with a national appeal and significance. Moreover, in terms of investments and policymaking Schiphol had outgrown the capabilities of the local government. In order to reach its desired status as the Dutch national airport a new collective arrangement had to be established, which involved the return of the national state as the key actor. Bringing the state back in, however, also involved a risk for Schiphol, as our discussion of the Dutch airport battle has made clear. Only after long negotiations Schiphol would emerge as the main Dutch airport.

The early history of Schiphol has also shown that a basic collective arrangement can be transformed without losing its constituting components - as is illustrated by the continuous involvement of KLM and members of State Departments, responsible for safety regulations at the airport. Furthermore, in the case of Schiphol the transformation of the collective arrangement resulted in growing complexity. From 1958 onwards, after the national government had finally decided to appoint Schiphol as the Dutch national airport for international aviation, the number of actors directly or indirectly involved in the development of the airport increased substantially. The following graphs show the organization of networks of actors involved in the development of the airport during the pre-war and the post-war period. The graphical representation of networks of actors clearly shows the increased complexity of vertical, in terms of local-regional and national governance levels, and horizontal, between local and regional actors, interrelations (see graph 1). 


\section{Graph 1. Networks of actors involved in the development of Schiphol Airport between 1919 and $1939 \rightarrow$ [Insert graph about here]}

The growing complexity mirrors the growing importance of Schiphol for the urban and regional economy. From the end of the 1960s onwards Schiphol turned into a real catalyst for the urban and regional economic development. This was part of a process of economic transformation in Amsterdam. After the war strong efforts to 'industrialize' the Amsterdam urban economy, centering on the development of harbor-related (petro-)chemical industries, eventually failed. From the 1960s onwards this modern, industrialist municipal policy would be overtaken by events which resulted in the - sometimes harsh - realities of post-industrialism like the deindustrialization of employment and population decline; Amsterdam's population fell from its peak of 869.000

inhabitants in 1960 to 676.000 in $1984 .{ }^{55}$ In the meantime, however, the importance of Schiphol for both the Amsterdam and the national economy grew significantly. From the 1960s onwards, the economic (and spatial) effects of Schiphol seem to be regionally widespread but strong economic benefits have been limited to Amsterdam and the wider Schiphol region. ${ }^{56}$ As our study has shown, in the case of Schiphol the creation of the airport and airport services, as well as the development of civil aviation during the 1920s and 1930s did not yet act as an important boost for the economic development of the region. The early history of Schiphol is, therefore, not so much related to economic, but also to institutional developments. A number of factors have been important during the early decades of its existence.

First of all, the close cooperation and personal influence of key figures like KLM director Plesman, Schiphol director Dellaert, Fokker, and mayor de Vlugt seems to have been decisive for the success of the airport in its early years. Each had their own vision, ambition and objective, but they all played an essential role in determining the future of Schiphol. In fact together, these actors 
formed a coalition organized around conventions, agreements and rules, which to a great extent shaped the history of Schiphol during the interwar years. As true believers of the winged gospel, the Amsterdam urban government in particular was willing to take risks and invest in the development and the extension of their municipal airport, despite the economic crisis of the 1930s and despite the fact that Schiphol could not generate enough financial means to sustain its ambitious expansion plans. Rotterdam and The Hague lacked such a conglomerate of local authorities, businessmen and aviation enthusiasts which could catalyze airport development in or near their cities.

Second, the early development of Schiphol was guided by civic pride and local boosterism, urban competition, political considerations and great enthusiasm about civil aviation technology, airport infrastructure and the modernism and heroism which surrounded the early history of aviation. From an economic point of view, the airport Schiphol (and the KLM for that matter) may seem an example of very inefficient business. During the early years of the airport, economic rationality, however, seems not to have played a major role. From the second half of the 1920 s, the Amsterdam urban government conveyed a strong sense of urgency, of the necessity to somehow grab the chance, provided by Schiphol, to make a significant leap in the development of their city. Schiphol played a significant role in local boosterism, as was illustrated by the use of the airport to market a 'modern' image of the city, and was used as an instrument to attract investments and boost the local economy. In 1928, when Amsterdam hosted the Olympic Games, Schiphol was used to market the city as a touristic, modern city and as the economic capital of the Netherlands. ${ }^{57}$

Third, the development of Schiphol benefitted from the fact that the airport design was conceived in the very early stages of the existence of Schiphol and provided for an excellent framework for discussions on the future development of the civil aviation in the Netherlands as a whole and the future of the airport Schiphol with regard to the national economy in particular. ${ }^{58}$ These discussions were fed by formal and informal relationships between airport operators and professionals of civil aviation. Circulation of information about the technological development of 
aviation and airport construction requirements took place through direct (meetings, conferences, work-visits) or indirect contacts (correspondence, professional magazines) within and between different networks worldwide. Moreover, in Amsterdam the results of this cross-fertilization of knowledge spillovers was used to construct plans for the future development of the airport. From the early 1930s, Amsterdam integrated the planning of Schiphol into the Amsterdam Development Plan (AUP) and into the urban development plan of the Haarlemmermeer and set up a special municipal commission to study and prepare the expansion of Schiphol, which clearly showed the growing importance of the airport for the surrounding areas and the region as a whole. ${ }^{59}$ At a very early stage in the development of Schiphol and although most of the airports at that time were operating at a loss, Amsterdam authorities had developed a clear vision on the future of their airport and appeared to be fully aware of the importance of airport development for the regional economic growth.

Finally, this study has aimed to contribute to an ever growing number of studies on airport history by focusing on the initial stages of airport development. Studying the inter war period appears to offer us relevant insights in the process of creation and development of airports and, more importantly, helps us to understand which actors and factors have contributed to the formation of collective arrangements which, to a great extent, determined the creation and development path of airports and their relationship with the surrounding urban area. In order to get to grips with the present position and importance of airport development at the regional level, one should therefore study the causes and consequences of its emergence during the pioneering era. 


\section{NOTES}

1 'Demonstratie voor het behoud van Schiphol', Het Vaderland 3 July 1938, morning edition.

${ }^{2}$ Ibid.

${ }^{3}$ M. Dierikx, and B. Bouwens, Building Castles of the Air: Schiphol Amsterdam and the development of Airport Infrastructure in Europe, 1916-1996 (The Hague, 1997).

${ }^{4}$ D. Brodherson, What Can't Go up Can't Come Down. The history of American airport policy, planning and design (Ann Arbor, 1993); D. Douglas, "Airports as systems and Systems of Airports: Airports and Urban Develop In America before World War II," in William M. Leary ed., From airships to Airbus: The History of civil and Commercial Aviation', volume 1: Infrastructure and Environment (Washington DC, 1995); John Myerscough, "Airport Provision in the Inter-War Years," Journal of Contemporary History, 20 (1985): 41-70; Dierikx and Bouwens, Building Castles; Other relevant studies include: J. Zukowsky, ed., Building for Air Travel: Architecture and Design for Commercial Aviation (Munich and New York, 1996); R. van der Linden, Progressives and the Post Office: Air Mail and the Creation of the U.S. Air Transportation, 1926-1934 (Ann Arbor, 1997); Frances Fiorino, "Recapturing the Dream: A Design History of New York's JFK Airport," Aviation Week \& Space Technology 164 (2006): 64; Frans van Humbeek, Brussels airport: the history of Haren, Melsbroek and Zaventem (Nieuwkerken-Waas, 2002).

${ }^{5}$ For a short survey of these studies, see Janet R. Daly Bednarek, America's Airports: Airfield Development, 1918-1947 (College Station, 2001): 4-5 and John R. Breihan, 'Review essay: airport history', Journal of Urban History 34 (2008): 850-854.

${ }^{6}$ Bednarek, America's Airports.

${ }^{7}$ See also Breihan's concluding remark: Breihan, 'Review essay', 853.

${ }^{8}$ See for example; E. S. Miller, "Institutional Economics: Philosophy, Methodology and Theory," The Social Science Journal, 15 (1978): 13-25; R. C. O. Matthews, "The Economics of Institutions and the Sources of Growth," The Economic Journal 96 (1986): 903-918; M. C. Rutherford, Institutions in Economics: The Old and the New Institutionalism (Cambridge, 1994); O. E. Williamson, "The New Institutional Economics: Taking Stock, Looking Ahead," Journal of Economic Literature 38 (2000): 595-913; R. R. Nelson and B.N. Sampat, "Making sense of institutions as a factor shaping economic performance" Journal of Economic Behavior and Organization 44 (2001): 31-54; T. Eggertsson, Economic behaviour and institutions (Cambridge, 1990); R.N. Langlois, "Rationality, institutions, and explanation," in R.N. Langlois, ed., Economics as a Process. Essays in the New Institutional Economics (Cambridge 1986).

${ }^{9}$ Cf. H. de Mare and A. Vos, eds., Urban rituals in Italy and the Netherlands. Historical contrasts in the use of public space, architecture and the urban environment (Assen, 1993), 5-25; E.H. Gombrich, "The visual image: It's place in communication" in Gombrich, The image and the eye. Further studies in the psychology of pictorial representation (Oxford, 1982), 138-140.

${ }^{10}$ At first the Ministry of War had opted for a artillery site to the north of the North Sea Canal and an artillery fire terrain at the Zeeburgerpolder in the eastern part of Amsterdam,

${ }^{11}$ M. Dierikx, Blauw in de lucht. Koninklijke Luchtvaart Maatschappij, 1919-1999 (The Hague, 1999).

${ }^{12}$ Among others the Dutch Trade company, the Rotterdam and Twente Bank, The House of Finance of Lippmann, Rosenthal and Co from Amsterdam, The Batavia Oil Company, and a couple of shipping companies.

${ }^{13}$ E.L.T.A. Eerste Luchtverkeer Tentoonstelling Amsterdam: augustus-1919 (Amsterdam, 1919). 
${ }^{14}$ The military authorities fixed the landing fee for commercial aircraft at 1 cent per power horse per landing. The military staff in turn provided for airfield services such as assistance during landing and departure, filling fuel and water tanks and weather information.

${ }^{15}$ R. Leeuw; Albert Plesman; Luchtvaartpionier en visionair (The Hague, 1989).

${ }^{16}$ H.A. Somberg, "Plesman, Albert (1889-1953)" in Biografisch Woordenboek van Nederland 2 (The Hague, 1985).

${ }^{17}$ G.M. Greup, Gedenkboek samengesteld ter gelegenheid van het 125-jarig bestaan [van de] Kamer van Koophandel en Fabrieken voor Amsterdam II, Het tijdvak 1922-1936 (Amsterdam, 1936), 165-166, 172-174.

${ }^{18}$ Amsterdam City Archive (hereafter ACA), Gemeenteblad 1926-II. City council minutes.

${ }^{19}$ ACA, Dienst Luchthaven Schiphol Archive (hereafter: 1323), nr. 69/12. Negotiations with the Ministry of War. Unfortunately, the Schiphol Archive, located at the Amsterdam City Archive, lacks a proper inventory. The notes refer to Dossier Numbers which can be retrieved on the documents themselves.

${ }^{20}$ Author note (see separate page).

${ }^{21}$ ACA, 1323, Dossier No. 17/135-S45; Dossier No.19/1011 S35 and 1471.S35.

${ }^{22}$ Ernst Heldring, Herinneringen en dagboek van Ernst Heldring (1871-1954) I-III. Joh. de Vries ed. (Groningen, 1970).

${ }^{23}$ Ch.A. Cocheret, Kamer van Koophandel en Fabrieken voor 's-Gravenhage: 1 october 1853 - 1 october 1953. Herinneringen aan 100 jaar (Tbe Hague, 1953), 203, 209, 222, 247, 280; G.M. Greup, Kamer van Koophandel en Fabrieken voor Amsterdam. Gedenkboek samengesteld ter gelegenheid van het 125 jarig bestaan II, Het tijdvak 1922-1936 (Amsterdam, 1936) 165-166, 172174; J. Verseput, Kamer van Koophandel en Fabrieken voor Rotterdam, 1928-1953 (Rotterdam 1955) 170-188, 217, 234, 283-292; Johannes de Vries, 1811-1961 met Amsterdam als brandpunt. Honderdvijftig jaar Kamer van Koophandel en Fabrieken (z.p. 1961).

${ }^{24}$ Author note (see separate page); Amsterdam City Archive, Public Affairs Archive (5181), inv. nr. 4125. no. 1761. Mayor De Vlugt to Van Tuyll van Serooskerken, 23 May 1922; Paul Arnoldussen, Amsterdam 1928. Het Verhaal van de IXe Olympiade (Amsterdam, 1994), 14.

${ }^{25}$ Author note (see separate page).

${ }^{26}$ Most of these active people were aware of the lagged position of the Netherlands in the field of aeronautics and civil aviation, compared to other European countries. The aviation magazine 'Het Vliegveld', which was close to the KNVvL, for example published in 1918 a series of articles and studies on the development of the aviation technology, civil aviation and the rise of commercial airports in Europe. In the issue of June 1918, Het Vliegveld published a detailed study on the Danish plans to position Kopenhagen as the most important gateway in emerging European air traffic network. According to this magazine, the Netherlands was potentially much more favored (geographically and economically) to serves as gateway in air traffic between the north and south of Europe.

${ }^{27}$ From 1945, Prof. Zwiers was the chairmen of the national commission on airfields which designated Schiphol as the solely international airport of the Netherlands and advised the state to create Schiphol airport company as new organisational form of the airport (1957).

${ }^{28}$ ACA, 1323, Commission for the Expansion of Schiphol Municipal Airport (various discussion reports ), 1010 S1935, 1471S1935 and 531.

${ }^{29}$ Paul Barrett, "Cities and their Airports: Policy Formation, 1926-1952," Journal of Urban History 14 (1987): 112-137, there 114.

${ }^{30}$ Bouwens and Dierikx, Building Castles, 51; ACA, 1323, 1010 and 1011 (1935). 
${ }^{31}$ ACA, 1323, No.932a-b-S49 (Draft version of an article written by the Managing director Jan Dellaert intended to be published in the 'World construction' magazine under the title: Schiphol: World Airport).

${ }^{32}$ Bouwens and Dierikx, Building Castles; Alastair Gordon, Naked Airport: A Cultural History of the World's Most Revolutionary Structure (Chicago, 2008), 65-87.

${ }^{33}$ See Dierikx and Bouwens, Building Castles, 32-46

${ }^{34}$ Ibid; 44-45.

35 See John Myerscough, "Airport Provision in the Inter-War Years," Journal of Contemporary History, 20 (1985): 41-70.

${ }^{36}$ Piet de Rooy, "In het voetspoor van de radicalen 1889-1902," in Remieg Aerts and Piet de Rooy, eds., Geschiedenis van Amsterdam III, Hoofdstad in aanbouw 1813-1900 (Amsterdam, 2006), 519573; Joh. de Vries, "De handelsstad. Verandering van de economische centrumfunctie," in Martha Bakker ed., Amsterdam in de tweede Gouden Eeuw (Bussum, 2000), 186-208.

${ }^{37}$ Paul van de Laar, Stad van formaat. Geschiedenis van Rotterdam in de negentiende en twintigste eeuw (Zwolle, 2000); Piet de Rooy, "Het middelpunt van het vaderland 1901-1914," in Piet de Rooy ed., Geschiedenis van Amsterdam IV, Tweestrijd om de hoofdstad 1900-2000 (Amsterdam, 2007), 17-73.

${ }^{38}$ Verseput, Kamer van Koophandel, 170-188, 217, 234, 283-292.

${ }^{39}$ In 1924 Dutch businessmen chartered a Fokker F-VII to make a direct non-stop flight from Amsterdam to Batavia. They eventually reached Batavia, albeit after a forced stop in Bulgaria.

${ }^{40}$ Bednarek, America's Airports, 7.

${ }^{41}$ Bouwens and Dierikx, Building Castles, 52-54; De Groene Amsterdammer March $6^{\text {th }} 1932$; ibid. October $8^{\text {th }} 1927$; ibid. August $6^{\text {th }} 1932$; For an excellent overview of the pre-war period concerning the enthusiasm about the effects of aviation technology on the public imagination, see David, T. Courtright, Sky as Frontier: Adventure, Aviation and Empire (College Station, 2005).

42 Jan Willem de Wijn, Woorden en daden in de geschiedenis van de Rotterdamse luchtvaart (Rotterdam, 2006), 38, 46.

${ }^{43}$ Ibid., 74-75.

${ }^{44}$ Verseput, Kamer van Koophandel, 173.

${ }^{45}$ Cocheret, Kamer van Koophandel, 209.

${ }^{46}$ Rotterdam Municipal Archive (GAR), General Affairs Archive (NSA/AZ; 444.01), inv.nr. 4210, no. 415; Bouwens and Dierikx, Building Castles, 92; Verseput, Kamer van Koophandel, 177.

${ }^{47}$ Verseput, Kamer van Koophandel, 170-188.

${ }^{48}$ Bouwens and Dierikx, Building Castles, 57.

${ }^{49}$ ACA, Archive 5169, inv.nr. 216, no. 2/35. Documents concerning the inauguration of Schiphol in 1938.

${ }^{50}$ ACA, Dossier No 17/ 739; 777 S39; 717 S46; 27, 7; 73DH1938; 713DH1946; see also Bednarek, America's Airports.

${ }^{51}$ ACA, Annual Report of the Municipality of Amsterdam, 1938; Bouwens and Dierikx, Building Castles, 93-96.

${ }^{52}$ Verseput, Kamer van Koophandel, 181-188.

${ }^{53}$ ACA, 1323, 832a-z-DH1940/51; No. 252.S.1940; National Archives (The Hague; hereafter NA), Archieven van de Noodcommissie Luchtvaartterrienen, 1945-1946 (hereafter: 2.16.39), Dossier No. 25-32.

${ }^{54}$ ACA, 1323, No. 309-S43, 51III; No. 305-S43, 51III; No. 138-S43, 51III; No. 316 S42, 51; No.3/35S, 51III; No. 262S, 51III; No. 311-543, 51 III; No. 102S, 51III; No. 832-DH1940, No 51II; No. 252.S.1940; see also, NA, 2.16.39., Dossier No.25-32. 
${ }^{55}$ De Vries, "De handelsstad," 200-208; Doeko Bosscher, "De oude en de nieuwe stad," in De Rooy ed., Geschiedenis van Amsterdam IV (Amsterdam, 2007): 348-374.

${ }^{56}$ P. Bleumink, W. Manshanden, and J. Veldhuis et al., Economische effecten Schiphol (BCI, TNO \& SEO, Amsterdam, 2006) see

http://www.verkeerenwaterstaat.nl/Images/br.7955.\%20bijlage\%203_tcm195-160749.pdf

${ }^{57}$ Author note (see separate page).

${ }^{58}$ ACA; 1323, No. 31-543, 51II; No. 102S, 51III; N0. 316S. 1942, No.51 and No 51II.; No. 823DH1940, No. 51II and No. 252. S.1940.

${ }^{59}$ Vincent van Rossem, Het algemeen uitbreidingsplan van Amsterdam. Geschiedenis en ontwerp (Rotterdam, 1993). 